\author{
20세기 서구 남성 수염 스타일의 상징적 가치 \\ 장미숙 ${ }^{1} \cdot$ 이화순 ${ }^{2} \cdot$ 이연희 $^{3}$ \\ 1숙명여자대학교 사회교육대학원 미용예술전공, ${ }^{2}$ 안산공과대학 뷰티디자인과, ${ }^{3}$ 한국국제대학교 미용예술과
}

\title{
The Symbolistic Values of Western Beards' Style in the Twentieth Century
}

\author{
Mee-Sook Chang ${ }^{1}$, Hwa-Soon Lee ${ }^{2}$, and Yon-Hee Lee ${ }^{3}$ \\ ${ }^{I}$ Dept. of Beauty Design, Graduate School of Social Education, Sookmyung Women's University; Seoul, Korea \\ ${ }^{2}$ Dept. of Beauty Design, Ansan Technical College; Ansan, Korea \\ ${ }^{3}$ Dept. of Beauty Design, Internationl University of Korea; Seoul, Korea
}

\begin{abstract}
The purpose of this study is to research the symbolistic values of western beards' style in the twentieth century. Namely, it is to consider the relationship between social-cultural factors and aesthetic meanings of western beards' style. The contents are, firstly, studying the conception and the types of beard. A beard is the hair that grows on a person's chin, cheeks, neck, and the area above the upper lip. At the World Beard \& Moustache Championships, there are moustache category (natural, english, hungarian, dali, fu manchu, freestyle), beard category (natural, musketeer, goatee, sideburns, freestyle), and full beard category (natural, garibaldi, verdi, van dyck, freestyle), Secondly, this paper is continued by researching the history of beard from the ancient to the present day, and thirdly, analyzing political dictatorship, social resistance and expression of personality, religious dignity, related with the change of world situation, the formation of postmodern anti-culture and pop-culture, and the coexistence of traditional culture. There are long and bushy full beards in some religions like Hinduism, Judaism and Islam. The meanings of their beards are purity, life and holiness. The beards of some politicians symbolize dictatorship. Namely, the chaplin of Hitler, the moustache of Hussein and the musketeer of Castro express strong power and charisma. In 1950s'-70s' subcultures, Hipsters' goatee, Bikers' horseshoe, Beat generations' goatee and Hippies' natural represent the lack of adaptability and social resistance. Also, the celebrities and artists like Ronald Colman, Clark Gable, Don Johnson, George Clooney, and Salvador Dali express freedom, personality, and taste with beards. For that matter, the symbolistic values of beards' style in the twentieth century are the religious dignity, the political dictatorship, the social resistance and the expression of personality. Today the beards' style is one of fashion items as well as a symbol of masculinity, customs and classes.
\end{abstract}

Key words: beard, dignity, dictatorship, resistance, personality

\section{1. 서 론}

오늘날 포스트모더니즘의 시대적 정서를 반영하듯 사회 전 반에 성적 고정관념의 해체가 이루어지고 있으며, 이러한 현상 은 미용문화에도 확산되어 남성의 외모 가꾸기가 일반화되고 있다. 이에 따라 패션을 포함한 화장, 헤어, 피부 관리, 몸매 관리, 성형에 이르기 까지 과거 여성의 전유물에 대한 양성 공 유 현상이 일어나고 있으며, 남성성을 상징하는 수염까지 멋 내 기의 일환으로 패션화 되는 경향이 나타나고 있다.

특히 ‘수염이 석자라도 먹어야 양반’이라는 우리나라 속담과 ‘턱수염 없이 영광을 받을 자격이 없다'(Chins without beards deserve no honour)라는 스페인 속담에서와 같이, 수염은 예로 부터 동서양을 막론하고 가부장적, 봉건적 사회체제 속에서 남

Corresponding author; Mee Sook Chang

Tel. +82-11-222-0001, Fax. +82-2-6203-2214

E-mail: ksscms@empal.com
성 고유의 권위와 계급, 카리스마를 표출하는 전근대적 요소로 여겨져 왔다. 그러나 1950-70년대에 서구에서는 청소년 반문화 와 결합되어 저항의 의미로 사용되기도 하였고, 최근에는 하나 의 패션 아이템으로서 자신의 매력과 능력을 드러내는 개성의 의미로 전환되는 등 변화하는 시대상을 반영하는 사회문화적 요소로서의 가치를 표출하고 있다.

지금까지 수염에 관한 선행연구들은 사극분장(김용선, 2008; 박대현, 2007)과 무대분장(강명주, 2003)을 위한 표현기법, 특정 시대의 수염 스타일(김경희 외, 2007)에 대한 연구가 주로 이루 어져, 20 세기 전반에 대한 사회문화적 측면에서 수염에 대한 논 의가 미미한 실정이다.

따라서 본 연구는 시대사적 변인에 의한 수염의 생성과 소 멸 및 규제 현상이 두드러지게 나타난 서구 수염 문화와, 그 시대를 풍미한 인물들의 성격에 따른 다양한 수염 형태에 주목 하고, 이에 대한 이론적 고찰을 바탕으로 현대 미용문화에 나 타난 남성 수염 스타일의 상징적 가치를 분석해보는데 연구의 목적이 있다. 
연구내용을 살펴보면 다음과 같다. 첫째, 이론적 배경으로 수 염의 정의 및 종류를 살펴보고, 수염에 대한 역사적 고찰로서 수염이 일반화 되어온 서구문화를 중심으로 고대로부터 20세 기에 이르기까지 시대에 따른 수염의 존재여부와 형태변화를 살펴보았다. 둘째, 상기의 내용을 바탕으로 현대, 특히 수염의 사회문화적 의미의 가변성이 두드러진 20 세기를 중심으로, 수 염 스타일이 표출하는 상징적 가치를 분석하였다. 연구방법은 사회, 문화 및 미용예술에 관한 국내외 문헌과 선행연구, 인터 넷자료를 중심으로 연구를 진행하였다. 지명, 인명은 한글과 원 어를 모두 사용하여 표기하고 수염 관련 명칭 및 영화제목은 원어로 표기하였음을 밝힌다.

\section{2. 이론적 고찰}

\section{1. 수염의 정의 및 종류}

사전적 정의에 따르면 수염은 '성숙한 남자의 입가-턱 - 볼 에 나는 털'(동아출판사 편집부, 1985)을 의미한다. 수염은 사춘 기 이후 남성 호르몬의 작용에 의해 생기는 제 2 차 성징으로, 개 인의 유전과 환경적 특성에 따라 다를 수 있으나 일반적으로 입술 위쪽 구석에서부터 나기 시작하여 입술 위 전체에 콧수염 이 형성된 후 볼 위쪽과 입술 아래쪽에 털이 나고, 결국 턱의 양옆과 아래, 얼굴 아래 나머지 부분에 광범위하게 나면서 전 체 수염이 형성되는 과정을 거친다. 평균적으로 남성은 턱에 25,000 개의 털이 있고, 수염이 매년 $125-150 \mathrm{~mm}$ 정도 자란다 ("Moustache", 2008).

영어에서 'Beard'는 수염을 통틀어 의미하기도 하나, 특히 얼 굴의 위 - 아래를 구별할 때는 턱 아래 부분의 수염을 턱수염, 즉 'Chin beard'로 지칭하고, 턱과 볼에 있는 수염을 면도하고 입술 윗부분에만 기르는 것을 콧수염, 즉 'Moustache'라고 하 며, 연결되지 않은 턱수염과 콧수염을 합쳐 특별히 'Van Dyck' 라고 한다(“Beard", 2009).

수염은 여러 가지 형태로 분류할 수 있는데 본고에서는 세 계적인 수염 경연 대회인 'World Beard and Moustache Championship' 종목을 참조하여 수염의 종류를 분류하였다. 단, 콧수 염(Moustache), 턱수염(Beard), 전체 수염(Full beard)으로 나누 어 각각의 경우마다, 인위적인 관리를 하지 않는 'Natural'과 아래의 종류에 해당되지 않는 모든 수염을 의미하는 'Freestyle'

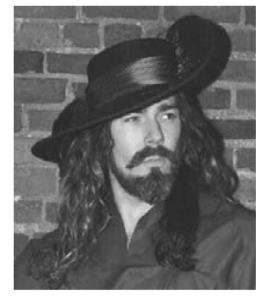

Fig. 6. Musketeer

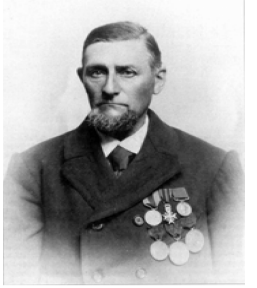

Fig. 7. Goatee

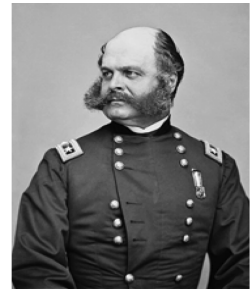

Fig. 8. Sideburns
은 제외하고 설명하기로 하겠다. 콧수염은 5 종이 있는데 첫째, 'English'(Fig. 1)는 좁은 수염이 윗입술의 중간에서 시작하여 구레나룻이 매우 길고 양옆에서 늘어져 살짝 컬이 있고, 그 뾰 족한 끝은 약간 위쪽으로 뻗어 있다. 입 양옆의 다른 부분은 면도한 형태이다. 둘째, 'Hungarian'(Fig. 2)은 크고 풍성한 수 염으로, 윗입술 중간에서 시작하여 입술 끝에서 최대 $1.5 \mathrm{~cm}$ 까 지 늘어지는 형태이고, 셋째, 'Handlebar'(Fig. 3)는 풍성하지만 수염 끝은 가늘고 위로 향하는 형태로, 자전거핸들처럼 생겨 붙 여진 이름이다. 이는 이탈리안 콧수염의 전형으로 'Spaghetti moustache'라고도 한다. 넷째, 'Dali'(Fig. 4)는 20세기 초현실 주의 화가 살바도르 달리(Salvador Dali)가 수염 끝으로 그림을 그린 이후 명명된 것으로, 좁고 끝이 길며 위쪽으로 깊게 구부 러진 형태이고, 다섯째, 'Fu Manchu'(Fig. 5)는 영화 <The Mystery of Dr. Fu Manchu>(1923)의 캐릭터 $\mathrm{Fu} \mathrm{Manchu}$ 의 수염 스타일을 의미하는 명칭으로, 뾰족한 수염이 아래로 향하 고 보통 턱을 지나갈 정도로 길며 때때로 너무 길어 발에 닿 기도 한다. 이 수염은 주로 중국 악당을 표현할 때 많이 사용 되는 것이다(“Fu Manchu moustache", 2009).

턱수염은 3종이 있는데 첫째, 'Musketeer'(Fig. 6)는 musket 이라는 긴 소총을 사용했던 현대식 군인을 말하며 Musketeer 의 수염형태는 구레나룻과 턱수염, 아랫입술의 밑 부분이 이어 져있다. 둘째, 'Goatee'(Fig. 7)는 턱에 자라는 수염으로, 숫염 소의 수염을 닮아 명칭이 지어졌다. 셋째, 'Sideburns'(Fig. 8) 는 미국 시민전쟁 당시 장군이었던 암브로스 번사이드(Ambrose Burnside)의 이름이 와전된 것으로, 관자놀이 부분의 헤어라인 에서 시작하여 귀를 지나 볼 아래로 턱 선을 향하고, 콧수염과 이어져 있으며 턱은 깨끗하게 면도된 독특한 형태이다 ("Sideburns", 2008).

또한 턱수염과 콧수염이 결합된 형태를 의미하는 전체 수염

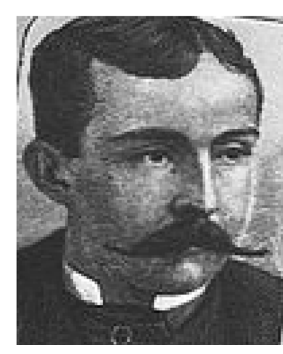

Fig. 1. English

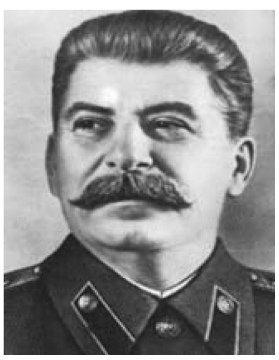

Fig. 2. Hungarian

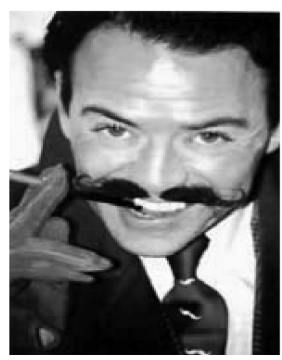

Fig. 3. Handlebar

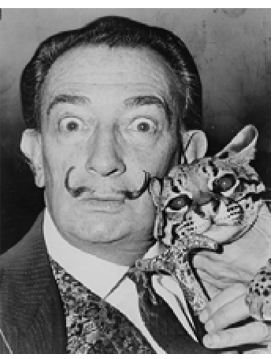

Fig. 4. Dali

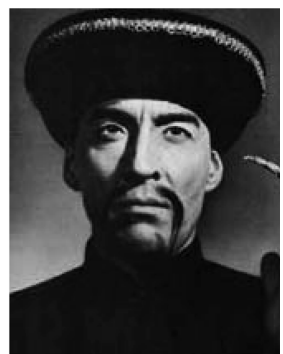

Fig. 5. Fu Manchu 


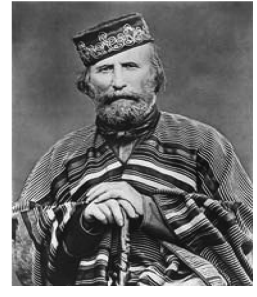

Fig. 9. Garibaldi

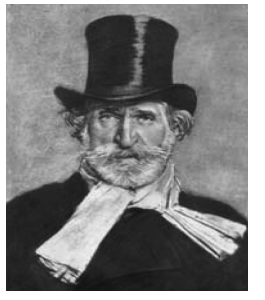

Fig. 10. Verdi

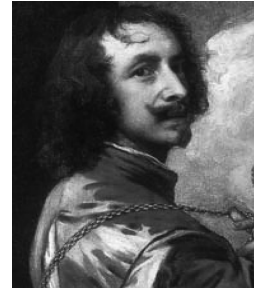

Fig. 11. Van Dyck
은 3종으로, 첫째 ‘Garibaldi'(Fig. 9)는 19세기 이탈리아 정치가 주제페 가르발디(Giuseppe Garibaldi)의 이름을 딴 것으로 아래 부분이 둥글고, 콧수염과 결합된 넓고 풍성한 수염이고, 둘째 'Verdi'(Fig. 10)는 19세기 이탈리아 낭만주의 작곡가 주제페 베 르디(Giuseppe Verdi)의 수염에서 유래하는데, 아래 부분이 둥 글고 짧은 형태의 수염으로, 콧수염이 두드러지며 볼 부분은 살 짝 면도된 형태이다. 셋째, 'Van Dyck'(Fig. 11)는 17세기 화가 안토니 반 다이크(Anthony van Dyck)의 그림에 등장하는 인물 들의 동일한 형태의 수염을 일컫는 것으로, 콧수염과 결합된 Goatee를 의미한다.(Sherrow, 2006).

\section{2. 수염의 역사적 고찰}

2.2.1. 고대

역사적으로 볼 때, 남성의 수염은 모양과 손질방법에 초점을 두고 있다. 고대 이집트에서 수염은 계급의 상징으로, 초기에는 주로 실제 수염이었고 점차 가짜 수염을 사용하게 되었으며, 계 급에 따라 수염의 길이가 달랐다. 땋아서 끝을 위로 구부러지 게 만든 수염은 신들에게만 허용되다가 후에 왕들에게도 사용 되었다(Corson, 2005). 왕은 염색이나 헤나염색을 하고, 때로는 금사로 엮은 턱수염을 착용하였으며 금속 메탈 가짜 수염과 통 치권의 상징인 모조품 장식 수염은 왕뿐 아니라 왕비들에 의해 서도 착용되었다. 앗시리아(Fig. 12), 바빌로니아, 칼데아, 메디 아, 고대 페르시아와 같은 메소포타미아 문명들은 수염에 오일 을 바르고, 작은 고리와 층이 있는 패턴을 만들기 위해 부젓가 락과 컬링 아이론(curling iron)을 사용하여 수염을 꾸몄다. 특 히 앗시리아 남성들은 특별한 날 수염에 금색 분말을 뿌렸고, 페르시아 왕들은 수염을 금실로 엮어 그 위에 금색 분말을 뿌
리기도 하였다(Sherrow, 2006). 당시 수염이 없는 남자들은 어 리석다고 여겨졌다(Corson, 2005).

고대 인도에서는 존엄과 현명함의 상징으로 수염을 길게 기 르는 것이 허용되었다. 동방국가들은 일반적으로 그들 수염을 잘 관리하고 소중하게 다루었고, 방탕함과 간통에 대한 처벌로 수염이 깎이기도 하였다. 그들은 부채에 대한 지불에 수염을 걸 고 약속하는 등 수염의 보존이 신성한 것으로 간주되었다. 고 대 그리스는 수염이 생식력의 상징으로 여겨져 수염이 없는 것 이 치욕스러운 것이었다. 호메로스(Homer) 시대에는 유태인들 사이에서 수염이 신성시 되어 간절한 소망의 표현으로 수염을 만지는 행동을 하였다. 애도의 표시로만 면도하였으며 부드러 운 얼굴은 나약함의 상징으로 간주되었다. 스파르타인들은 수 염의 일부를 면도함으로써 겁쟁이를 처벌하였다. 고대로부터 윗 입술의 면도는 일반적이었다. 그리스 수염 또한 부젓가락으로 컬하는 것이 보통이었다. 기원전 4세기경 알렉산더(Alexander) 제국 시대에 이르러 면도의 관습이 소개되었다. 알렉산더는 적 들의 손에 수염이 잡혀 군인들이 죽는 것을 두려워하여 그의 군대에게 깨끗이 면도하도록 명령하였다. 면도의 실행은 마케 도니아에 퍼졌고, 코인(coin)에서 마케도니아 왕들이 깨끗이 면 도한 모습을 볼 수 있다. 따라서 마케도니아 시대 이후 수염이 있는 남성은 철학자를 암시하였다. 그 당시 노예들 또한 수염 을 길렀으며 그들이 자유의 몸이 되었을 때 수염을 면도할 수 있었다(Corson, 2005).

고대 로마가 왕정과 초기 공화정을 거치는 동안 면도가 잘 알려지지 않았으나, 티시니우스(Ticinius)가 기원전 299년경 이 발사를 최초로 데려온 이후, 거의 모든 로마인들이 면도를 하 게 되었으며 이는 곧 그리스인이 아닌 로마인이라는 표시가 되 었다. 공화정 후기, 많은 젊은이들이 부분적으로만 수염을 깎고 장식을 하거나 수염의 빠른 성장을 위해 턱에 오일을 발랐다. 로마에서는 공화정 후기와 제국 초기 기간 동안 긴 수염이 게 으름과 불결함의 표시로 여겨졌다. 처음 면도는 성년의 시작으 로 간주되었고, 이날은 축제가 열렸다. 그리스와 달리 로마는 애도의 표시로 수염을 길게 내버려두었다. 2세기경 로마황제 하드리안(Hadrian)은 수염을 길렀는데, 이는 자신의 얼굴에 있 는 상처를 가리기 위한 것이었으나 많은 사람들이 그를 모방하 였다(“Beard", 2009).

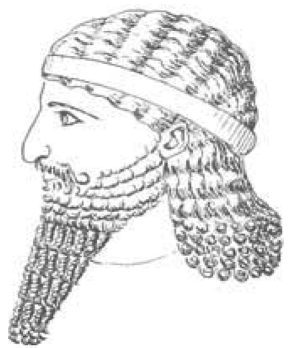

Fig. 12. 앗시리아 가짜수염

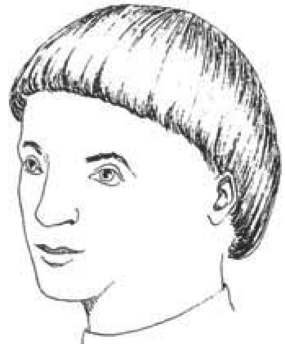

Fig. 13. 중세 성직자

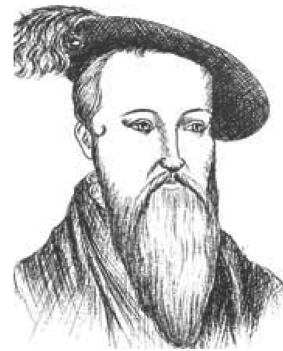

Fig. 14. Sugar-loaf beard

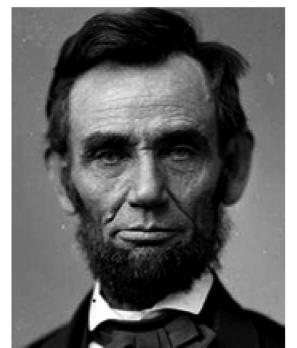

Fig. 15. Lincoln 


\subsection{2. 중세}

게르만족 이동으로 서구 역사에 등장하게 된 고트족, 프랑크 족, 갈리아족 등 야만인들은 긴 콧수염만 있고 턱수염이 없는 것이 일반적이었다. 로마 지리학자 스트라보(Strabo)에 따르면, 그들은 마치 날개처럼 가슴 위에까지 콧수염을 늘어뜨려 음식 을 먹을 때 음식을 건드리거나 그 액체에 수염을 적셨다. 기원 전 27년부터 서기 290년 갈리아에서 국민들은 끝이 뾰족한 턱 수염을 기른 반면, 귀족들은 콧수염을 길렀다. 수염은 자부심의 상징이었고, 때때로 염소의 지방과 너도밤나무의 재를 이용하 여 밝은 레드로 염색하였다. 앵글로색슨족은 한층 더 나아가 선 명한 그린, 오렌지, 블루 색상으로 염색하였다. 프랑크족 또한 턱수염 대신 콧수염을 길렀으나, 부족의 힘이 커지고 사회적 지 위가 부와 빈곤의 대조에 의해 결정됨에 따라 턱수염이 자유, 계급, 권위의 표시가 되었다(Corson, 2005).

반면, 중세 교회는 세속적이라는 이유로 남자들이 머리와 턱 수염을 길게 기르는 것을 규제하였다(Fig. 13). 7세기 후반 로 마 교황청과 영국, 스코틀랜드, 아일랜드 천주교회 간에 수염과 면도에 대한 격렬한 논쟁이 있었다. 로마 교황은 구원을 위해 면도가 필수 불가결하다는 입장을 취했고 영국 사제들은 면도 는 필요이상의 조치라고 반박했다. 그러나 싸움이 점차 격해지 자 파문과 제명을 두려워했던 군주 오스위(Oswie)는 성직자들 에게 턱수염, 콧수염, 구레나룻에 대한 금지령을 내렸고 위반 시 공개 참회를 선언하였다. 768년 프랑스 샤를마뉴(Charlemagne) 대제는 콧수염만으로 치장을 하고, 털이 있는 얼굴이 혐오스럽 다고 생각하여 신하들의 면도를 요구하는 특별 조건을 명시했 다. 11 세기 후반 교회의 규제를 무시한 채 다시 긴 턱수염이 유행하게 되자, 1073년 그레고리(Gregory) 교황은 면도를 거부 하는 성직자들의 재산을 몰수할 것을 명령하였다. 1094년 프랑 스에서는 최초로 공식적인 이발사 협회가 설립되었으며, 프랑 스 루앙(Rouen)의 대주교는 머리나 턱수염이 긴 사람들은 누 구든지 교회에서 추방하도록 선포하고 1096년 공식적인 법률 로 제정하였다. 1102년 베니스(Venice) 법령에서는 긴 턱수염을 금지하고 1105년 크리스마스 때 아미엥(Amiens) 주교는 턱수 염이 있는 사람에게 성찬해주는 것을 거절하였다. 또한 수도사 들은 겨울에는 한달에 두 번, 다른 계절에는 10 일에 한번씩 면 도하도록 요구되었다. 이와 같은 교회의 강한 규제로 말미암아 12-13세기에는 턱수염이 유행하지 않았으나, 14세기에는 다시 유행하였고 스페인에서는 다양한 색과 모양의 가짜 턱수염도 나타나 다른 사람으로 변장하는 것이 쉬워지자 경범죄가 성행 하였다. 아라곤(Aragon)의 왕이었던 피터(Peter)는 결국 가짜 턱 수염을 착용하는 것을 금지하였다(Corson, 2005).

\subsection{3. 근세}

르네상스 시대의 인본주의를 반영하듯, 16 세기가 되자 삽 모 양의 Spanish spade beard, 네모 모양의 English square cut beard, 두 갈래로 갈라진 Forked beard, 끝이 뾰족한 Stiletto beard, 숱이 풍성한 Bush beard, 원뿔 모양의 Sugar-loaf beard
(Fig. 14) 등 다양한 형태가 유행하였으며 염색도 행해졌다. 왕 족들은 수염 스타일을 유지하기 위해 궁중 이발사의 관리를 받 았다(Corson, 2005).

그러나 17 세기 이후 서유럽과 아메리카 대륙에서 수염이 유 행에 뒤떨어진 것으로 간주되어 1698년 러시아 대제 피터 (Peter) 1세는 남성들에게 수염을 자르도록 명령하고 러시아를 서유럽과 동등한 사회로 이끌기 위해 수염을 기르는 것에 세금 을 부과하였다(“Beard", 2009). 17-18세기는 남성들을 위한 가 발의 세기였던 반면, 귀족과 상류계급 사이에서 수염이 매우 드 물었기 때문에 상대적으로 이발사의 위상이 상당히 높았다.

2.2.4. 근대

19세기가 되자 가발이 사라지고 자연스럽고 짧은 헤어스타 일을 선호하게 되었으며 세기 초반 구레나룻이 처음 등장하였 고 1810 년 일반화 되었다. 턱수염과 콧수염에 대한 찬반 여론 이 뜨거운 가운데, 나폴레옹 시대가 되자 수염은 하나의 패션이 되어 러시아의 알렉산더 3 세, 프랑스의 나폴레옹 3 세, 독일의 프 레드릭 3세 등 많은 유럽의 군주들과 지도자들이 수염을 길렀 고(“Beard", 2009), 19세기 후반 대부분의 사람들은 턱수염, 콧 수염, 구레나룻의 다양한 결합으로 수염을 길렀다(Corson, 2005).

빅토리아 시대 남성은 긴 구레나룻이 있는 풍성한 수염에 검 정색 정장을 입은 엄숙하고 경건한 모습이 전형적이다(“Beard", 2009).

19세기 중반 많은 미국인들은 풍성한 수염을 하고 있었다. 아브라함 링컨(Abraham Lincoln, Fig. 15)이 1861년 대통령에 당선되었을 때 그는 수염을 기른 최초의 미국 대통령이 되었다. 시민전쟁이 끝난 후, 그는 Vogue 잡지에 더욱 수염이 풍성하고 성숙된 모습으로 나왔고, 그의 구레나룻은 현명함과 존경의 대 상으로 간주되었다. 1869년 만화가 토마스 나스트(Thomas Nast) 는 'Uncle Sam'이라는 그림을 그렸는데 주인공과 같이 길고, 얇고, 하얀 수염을 가진 남성이 미국의 상징이 되었다. 1800년 대 후반 영국의 에드워드(Edward) 7세는 우아한 의상과 수염 손질방법으로 남성들의 스타일에 영향을 주었다. 20세기 전환 기까지 서구의 다양한 문화 속에서 신사들은 에드워드와 같이 단정하게 손질한 수염을 하였다(Sherrow, 2006).

\subsection{5. 현대}

1895년 질레트(Gillette) 회사가 면도기를 발명한 이래, 수염 패션의 변화는 미국 대통령의 초상화에서 발견된다. 링컨 이후 1896년에 당선된 윌리엄 맥킨리(William McKinley)는 깨끗하 게 면도한 모습이었고, 1912년 당선된 우드로 윌슨(Woodrow Wilson) 시대에는 대다수의 남성들이 매일 면도하기 시작함에 따라 20세기 동안 백악관에서 수염이 사라졌다(Sherrow, 2006). 20세기 초 수염은 서서히 대중성을 상실하게 되고 새로운 면 도기구의 개발은 면도를 더 쉽고 편리하게 만들었다. 1910년 질레트 회사는 '여성들이 면도한 남성을 더 선호한다'는 광고 로 매일 아침 면도를 종용하였는데, 면도가 더 문명화된 것이 


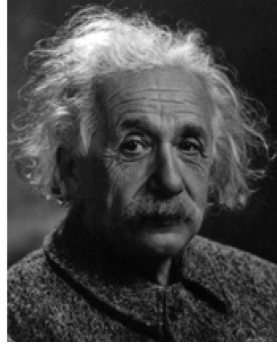

Fig. 16. Einstein

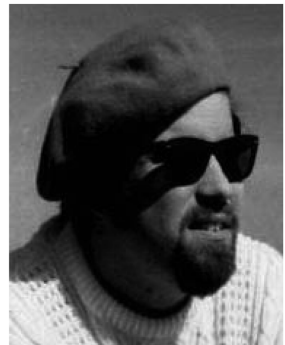

Fig. 17. Beat Generation

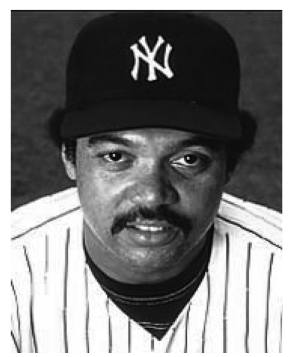

Fig. 18. Jackson

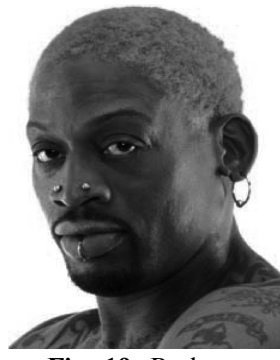

Fig. 19. Rodman
고 여성들이 깨끗하고 건강한 피부에 가치를 둔다는 데서 아이 디어를 얻어 활동적인 남성을 상징하는 건강한 외모를 가진, 수 염 없는 남성을 광고에서 보여주었다(Sherrow, 2006). 그러나 이러한 트랜드에도 불구하고 히틀러(Adolf Hitler), 스탈린(Josef Stalin, Fig. 2), 아인슈타인(Albert Einstein, Fig. 16)과 같은 교 수, 과학자, 예술가 및 지식인들은 여전히 수염을 선호하였다. 이들은 현대화의 물결 속에서 수염을 고수함으로써 남성적 권 위와 전통철학의 고수, 직업적 카리스마를 표출한 것으로 사료 된다. 특히 히틀러와 스탈린은 세계정세의 변화 속에서 민족주 의, 사회주의를 주장한 정치가로서, 깨끗하게 빗어 넘긴 헤어스 타일과 짙은 눈썹, 잘 정돈된 수염 등 외모를 통해 민중을 흡 인하는 지도력과 굳은 결의, 강한 자신감을 엿볼 수 있다. 1950-60년대 포스트모더니즘(Postmodernism) 시대의 도래는, 남 성/여성, 이성/감성, 문화/자연, 현대/전통, 서양/동양, 주류/비주 류 등 후자가 전자의 억압과 침묵을 강요받던 이분법적 경계가 와해되고 다원화 사회, 대중 사회로 이행하는 계기가 되었다. 이는 수염 문화에도 반영되어, 주류사회에서 면도 문화가 정착 된 가운데 1950년대에 청년 하위문화 힙스터(Hipsters), 바이커 (Bikers), 비트 제너레이션(Beat Generation, Fig. 17)들이 수염 을 기름으로써 사회에 대한 비동조성과 반항을 드러내었다. 또 한 1960-70년대에는 히피(Hippies) 운동의 영향으로, 자연 그대 로 기른 수염과 긴 헤어스타일이 서구 사회의 주류를 이루면서 ("Beard", 2009) 수염이 반문화의 상징이 되었다.

1970년대 초반, 일반인은 물론 메이저 리그 야구 선수들 또 한 수염을 거의 기르지 않았다. 몇몇 선수들만이 수염을 길렀다 가 시즌이 시작되기 전 수염을 잘랐다. 그러나 1972년 아메리칸 리그의 Oakland Athletics 팀 소속 레기 잭슨(Reggie Jackson, Fig. 18)은 수염을 풍성하게 기르고 정규시즌 동안에도 자르지 않았는데 이는 1914년 이후 처음 있는 일이었다. Oakland Athletics의 구단주 찰리 핀리(Charlie Finley)는 잭슨이 면도하 길 원했지만 큰 분쟁이 일어나길 원하지 않았기 때문에, 팀 내 에서 수염 콘테스트를 개최하여 다른 선수들이 수염을 기르게 함으로써 자신만의 개성을 중시하는 잭슨이 면도할 것으로 생 각했다. 짐 헌터(Jim C. Hunter), 롤리 핑거스(Rollie Fingers), 데럴드 노엘레스(Derald Knoeles), 밥 락커(Bob Locker) 등 4 명의 에이스 투수들이 수염을 길렀다. 1972년 월드 시리즈에서 팀의 룰이 '수염금지'였던 Cincinnati Reds 팀과 경기를 하게
되었을 때 언론에서는 'The hairs vs. the squares'(털복숭이 대 신사들)의 대결로 명명하였다. 특히 핑거스의 Handlebar 수 염은 월드 시리즈 경기 동안 미디어의 주목을 받았으며 수염은 곧 그의 상징이 되어 그를 스포츠 계에서 가장 유명한 선수로 만들었다(Parray, 2002를 Sherrow, 2006에서 재인용). Oakland Athletics팀은 수염을 기르는 것을 팀 전체의 룰로 결정하였으 며 다른 팀과 구별되는 특징적인 룩을 보여주었다. 선수들의 수 염에 생성된 지명도를 이용하기 위해 구단주는 ‘아버지의 날' (Father's Day)을 'Mustache Day'로 정하고, 홈 경기장에 수염 을 기르고 오는 관중들을 무료입장시켰으며 그날 수염이 있는 선수들에게는 300 달러의 보너스를 지급했다. Oakland Athletics 팀은 월드 시리즈 우승으로 'Mustache Gang'이라는 별명을 얻었 고(Sherrow, 2006), 이러한 팀의 성공과 패션의 변화에 따라 수 염은 다시 야구 선수들 사이에서 유행하게 되었다("Moustache", 2008).

1980년대 이후, 일부 남성들은 아침 면도 후 낮 동안 자란 수염을 의미하는 'Five o'clock shadow'라 불리는, 전체적으로 가볍게 기른 수염을 선택하였다(Sherrow, 2006). 영화배우 돈 존슨(Don Johnson)과 조지 클루니(George Clooney)는 하루 이 상 면도하지 않은 편안한 스타일을 선보였으며 톰 크루즈(Tom Cruise)는 더욱 덥수룩한 수염으로 남성미 넘치는 스타일을 보 여주었다. 또한 축구선수 데이비드 베컴(David Beckham), 농구 선수 데니스 로드맨(Dennis Rodman, Fig. 19) 등은 특유의 헤 어스타일, 화려한 컬러링과 수염을 하나의 패션 스타일로 제시 하며 패셔너블한 스포츠 스타로 주목을 받았다. 70년대 야구선 수들이 팀 간의 차별화를 위해 수염을 길렀다면 80년대 스포 츠맨들의 수염은 개인적인 차원에서 스포츠맨과 패션아이콘의 경계를 허물고, 운동에만 매진하던 과거의 인식과 달리 20 세기 대중문화의 상징인 셀리브리티(celebrity)로서의 존재를 드러내 는 것이라 할 수 있다.

20 세기 후반, 수염을 기르는 것은 하나의 이벤트가 되어 북 아메리카와 영국에서는 많은 수염 경연 대회가 개최되었고 오 늘날까지 이어지고 있다. 'November'의 경우 11 월에 열리는 자선 이벤트로, 남성의 건강 문제 특히 전립선암을 알리는 행사 로 진행되며, 수염 올림픽으로 알려져 있는 'World Beard and Moustache Championship'은 세계적인 대회로 1990년대에 독 일에서 시작되어 격년제로 주최국이 바뀌어 진행된다. 다양한 
수염의 형태와 길이를 가진 참가자들이 모여 정해진 시기 안에 가장 크고 잘 손질된 수염을 기르는 것이 참가자들의 최대 목 표이다. 이외에도 알라스카(Alaska)의 앵커리지(Anchorage)에서 는 매년 개최되는 '광부와 사냥꾼들을 위한 파티'(Miners and Trappers Ball)에서 수염 상을 시상하는데, 가장 훌륭한 수염을 가진 사람에게 수여되는 Mr. Fur Face상, 그리고 수염 색상에 따라 수여되는 Black bear, Brown bear, Honey bear, Polar bear, Red fox상으로 구분된다. 이탈리아에서는 매년 9월 그로 탈리에(Grottaglie)에서 'Beard and Moustache Festival'이 개 최되고 있다(Sherrow, 2006). 이러한 대회에서 수염은 남성다움 의 상징이 되고, 우승자는 경쟁자들 중 가장 남성적인 것으로 간주되고 있다(“Beard", 2009).

그러나 이와는 상이한 현상으로, 힌두교, 유대교, 이슬람교를 비롯한 일부 종교인들은 얼굴 하단 부분 전체를 가릴 정도로 풍성한 수염을 기름으로써 민족의 종교적 관습과 율법을 지키 고 타종교와의 차별성을 추구해오고 있으며, 이는 과학과 이성 에 의한 현대 문화만을 고집하지 않고 전통과의 소통을 통해 다원성을 표출하는 포스트모더니즘의 한 현상이라 할 수 있다.

이처럼 20세기 남성들의 수염은 개인적 직업과 라이프스타 일 또는 그들의 종교 및 정치적 신념을 표현하고 있으며 연예 인과 스포츠 스타를 중심으로 수염은 하나의 패션 아이템이 되 었다.

상기의 내용을 통해, 수염에 영향을 미친 사회문화적 요인은 민족과 이념적 가치관에 의한 세계의 정치적 변화, 포스트모더 니즘에 의한 반문화와 대중문화의 형성, 전통문화의 혼재를 추 출해낼 수 있다.

\section{20세기 서구 남성 수염 스타일의 상징적 가치}

본 장에서는 20 세기 서구 남성 수염 스타일에 영향을 미친 사회문화적 요인을 바탕으로, 수염 스타일의 상징적 가치를 분 석한 결과, 논자의 주관적 분석에 따라 정치적 독재, 사회적 반 항, 개성적 표현, 종교적 권위로 분류하여 연구를 진행하였다.

\section{1. 정치적 독재}

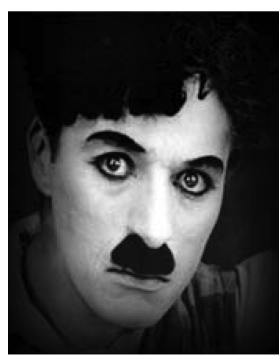

Fig. 20. Chaplin

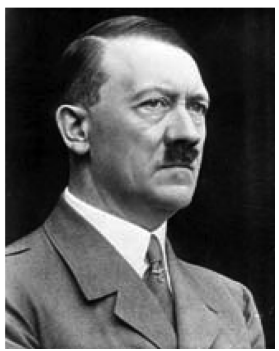

Fig .21. Hitler

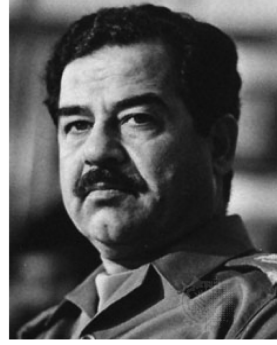

Fig. 22. Hussein

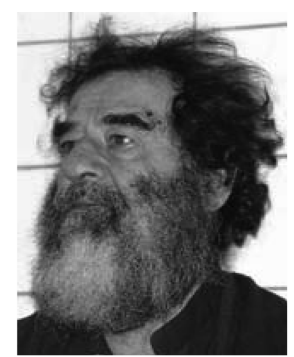

Fig. 23. Hussein

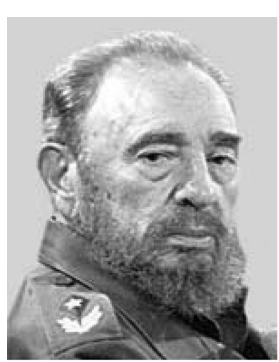

Fig. 24. Castro
'Chaplin'(Fig. 20)이라 이름 붙여진 코 밑 수염은 본래 영국 의 희극배우 찰리 채플린(Charlie Chaplin)이 독일의 정치가 아 돌프 히틀러(Adolf Hitler)의 수염을 통해 그의 독재를 풍자하 기 위한 것이었다(“몸 이름”, 2009). 일명 “Toothbrush'라고도 불리는데 수염 숱이 많지만 코 밑 가운데 $2.5 \mathrm{~cm}$ 만 남기고 면 도된, 칫솔과 같이 생긴 수염이다(“Moustache”, 2008).

1933년 나치당 1당 독재 체제를 굳힌 히틀러(Fig. 21)는 1934년 파울 폰 힌덴부르크(Paul von Hindenburg) 대통령이 사망하자 절대 권력자가 되었고 세계정복에 대한 야망으로 제 2차 세계대전을 일으켰다. 히틀러의 사상은 우파의 급진주의를 이어받아 독일 민족 지상주의와 유대 민족에 대한 반감을 바탕 으로 동방대제국의 건설, 동방으로의 게르만족 진출, 열등한 민 족의 절멸(絕滅) 및 추방 등 시류에 역행하는 세계관을 고집하 며 무고한 사람들을 학살하고 마침내 자신도 파멸하였다(“히틀 러”, 2004). 턱은 깨끗하게 면도한 채 코 밑에 좁게 기른 히틀 러의 콧수염은 이후 독재자의 트래이드 마크가 되었고, 일제시 대 우리나라를 식민화했던 일본 순사를 묘사할 때도 자주 등장 한다.

이라크 전 대통령 사담 후세인(Saddam Hussein)의 수염은 히틀러의 수염보다는 그 영역이 다소 넓지만 유사하게 콧수염 만을 보유하였다(Fig. 22). 잘 다듬어진 콧수염을 제외한 나머지 부분은 깨끗하게 정리함으로써 강인한 성격과 깔끔한 인상을 보여준다. 이라크 내 소수종파인 수니파 출신으로, 세속적 범아 랍주의와 아랍 사회주의를 추구하는 바트당의 지도적 인물이었 던 후세인은 1968년 군사 쿠데타를 계기로 대통령으로서 장기 집권(1979-2003)을 하게 되었다. 1990년 쿠웨이트 침공에 대해 미국 걸프전쟁과 유엔제제를 받았으며, 9.11을 비롯한 알카에 다(Al-Qaida)의 국제적 테러사건을 지원함으로써 미국으로부터 ‘악의 축'으로 규정되었다. 2003년 3월 20일 마침내 미국의 이 라크 공습이 시작되었고 후세인은 전범으로 체포되고 시아파 무슬림 학살에 대한 유죄가 인정되어 사형이 집행되었다(“사담 후세인", 2009). Fig. 23에서 보듯이 사형직전 풍성하게 기른 턱수염은 더 이상 스마트한 인상을 보여주지 못하고, 고통스러 운 심경과 고행을 표현하고 있다.

쿠바의 전 국가원수였던 피델 카스트로(Fidel Alejandro Castro Ruz)는 1959년 바티스타(Fulgencio Batista Zaldivar) 
독재정권을 타도한 혁명으로 쿠바의 지도자가 되었다. 그러나 반미노선과 사회주의 체제로의 전환으로 구소련으로부터 원조 를 받던 쿠바는 1980년대 말 공산권의 붕괴로 인해 경제가 몰 락하고 폐쇄국가로 진입하는 계기가 되었다. 국민적 영웅이었 던 카스트로는 정권의 생존을 위해 언론탄압, 지식인 감금, 정 적의 숙청, 동생 라울 카스트로(Raúl Modesto Castro Ruz)의 후계체제 구축 등 독재자로 변신하고 쿠바를 '카스트로 제국' 으로 둔갑시킴으로써 21세기 최후의 사회주의자로 인식되고 있 다(“파란의 인생역정”, 2008). 카스트로의 수염은 구레나룻과 턱수염, 아랫입술의 밑 부분이 이어진 'Musketeer' 수염으로 남 성적이고 마치 적에게 빈틈을 보여주지 않으려는 듯이 촘촘한, 군인 수염의 전형이라 할 수 있다(Fig. 24).

이상에서 살펴본 바와 같이 정치적 독재자의 수염은 강한 눈 빛, 굳은 결의를 보여주는 꼭 다문 입술과 어우러져 더욱 카리 스마 넘치는 강인한 인상을 보여준다.

\section{2. 사회적 반항}

수염이 반문화의 상징이 된 것은 1950-70년대 청년 하위문 화가 급속히 성장하면서 이루어졌다. 특히 힙스터(Hipsters), 바 이커(Bikers), 비트 제너레이션(Beat Generation), 히피(Hippies) 를 중심으로 독특한 수염형태가 나타났다.

1940년대 후반 영국은 제2차 세계대전의 종식으로 들떠있었 으나 일부 젊은이들은 사회분위기와는 동떨어진 채 어려운 재 즈(Jazz)에 심취하였다. 이처럼 뉴욕의 작은 재즈 클럽에서 새 롭고 실험적인 즉흥연주법 비밥(bebop)이 출현하면서 이에 열광 하는 젊은이들이 생겨났는데 이들을 힙스터라 불렀다(Polhemus, 1994). 아프로-아메리칸(Afro-american) 흑인의 설움과 향수를 표현하는 독특한 감성의 재즈는 인종을 넘어 유행하게 되었으 며 힙스터들은 평범한 라이프스타일을 거부하고 1940-50년대 하위문화가 되었다. 그들의 스타일은 베레모, 검은 선글라스 또 는 뿔테 안경, 염소수염 형태인 'Goatee', 넓고 화려한 스카프, 스트라이프 슈트가 특징이다. 힙스터의 'Goatee' 수염은 스타일 리쉬한 예술가적 감성을 보여주며 신사정장과의 부조화속에서 혁신적인 스타일을 연출하였다(Fig. 25).

1953년 영화 <The Wild One>으로 인해 생겨난 '바이커'들 은 전후 미국의 일상에 적응하지 못한 제2차 세계대전 참전 군

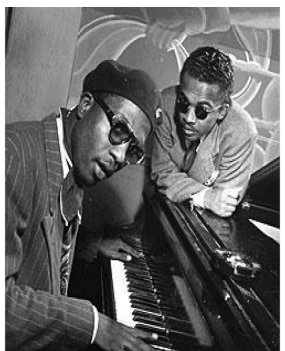

Fig. 25. Hipsters

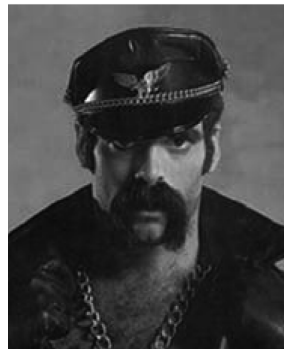

Fig. 26. Bikers
인으로, 당시 주류 사회에 맞추려는 동조적 성향을 부정하고 오 히려 급진적인 생활양식을 상징하는 모터사이클을 저항수단으 로 삼았다(양미경, 2003). 맥아더(Douglas MacArthur) 등 전쟁 영웅들의 스타일이었던 검정 가죽 재킷과 부츠를 차용하고 자 신들의 노동자계급을 상징하는 헤진 T셔츠와 청바지를 입음으 로써 갱(gang) 또는 사회적 인습을 벗어난 무법자로 인식되었다 (Polhemus, 1994). 그들의 초라하고 추레한 스타일은 풍성하고 지저분해보이는 수염으로 더욱 완성되었는데 특히 'Horseshoe' 수염(Fig. 26)은 양 입술 끝으로부터 수직으로 턱 선까지 내려 간 수염으로, 말굽의 U자형을 닮아 붙여진 이름이며 일명 'Biker Moustache'라고도 불린다(“Moustache”, 2008). 이는 마 초(Macho) 같은 터프함과 섹슈얼리티, 힘, 사회에 대한 비동조 성을 보여준다.

전쟁이후 냉전에 대한 환멸, 신비주의에 대한 열망, 사회적성적 억압으로부터 탈출하고자 했던(윤수경, 2003), 일명 ‘비트 제너레이션, 또한 사회에 대한 반항을 표출하는 형태로 수염을 길렀다. 비트 제너레이션은 1950 년대를 풍미했던 미국 작가들 을 묘사하는 용어이자, 그들이 소재로 삼았던 시대적 문화현상 을 의미하는 것으로 향후 '비트닉'(Beatniks)이라 불리기도 하 였다. 비트 문화는 미국의 주류적 가치에 대한 저항을 포함하 는 것으로, 마약, 섹슈얼리티의 변형과 동양 사상에 대한 관심 을 드러내었다(“Beat Generation", 2009). 그들은 검정 터틀넥 스웨터(turtleneck sweater)와 베레모, 어두운 선글라스를 쓰고 폭이 좁은 'Goatee' 수염을 선호하였다(Fig. 27). 비트 문화는 더욱 급속히 확산되어 히피로 이어졌다(“Beatnik”, 2009).

1960-70년대 반문화인 히피는 과학기술과 기계문명, 물질만 능주의, 베트남 전쟁으로 인한 휴머니즘의 상실감을 표현하는 하나의 방법으로 정치·사회로부터 이탈하여 스스로 도피하고 은둔함으로써 자유를 추구하였다. 그들은 인위적인 꾸밈없이 수 염을 기르고(Fig. 28) 의복을 자급하면서 자연 속에서 땅에 가 장 가깝게 생활하였다. 타락한 공동체 생활을 하고 마약을 통 해 현실을 회피한 부정적 모습 뒤에는, 자본가에 의한 착취를 규탄하고, 환경과 생태학에 대한 관심을 화두로 제시한 긍정적 인 측면이 있었다(윤수경, 2003). 이러한 히피운동의 영향으로 수염과 긴 헤어스타일이 서구 사회의 주류를 이루게 되었다.

상기 내용을 통해 20세기 면도하는 문화 속에서 그와 반대

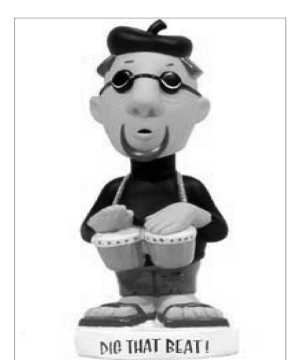

Fig. 27. Beatniks의 아이콘

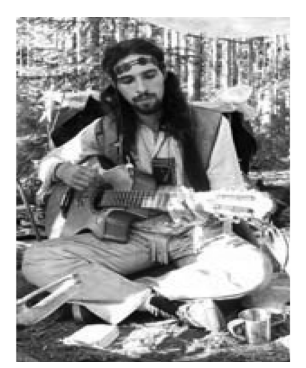

Fig. 28. Hippies 
로 하위문화권에서 수염을 기르는 것은 시대에 순응하지 않는 비동조성과 불만을 표시하는 하나의 방법이 되었음을 알 수 있 다. 수염은 자신들만의 문화적 정체성을 드러내는 하나의 수단 이 되었던 것이다.

\section{3. 개성적 표현}

성서 속에 등장하는 삼손(Samson)이 머리카락과 수염이 잘 린 후 힘을 잃듯이 남성에게 있어 수염은 남성성, 즉 물리적인 힘을 표현하는 상징물이었다. 오늘날 각자의 얼굴형과 선호도에 따라 잘 다듬어진 수염은 남성성을 표출할 뿐 아니라 자신의 성 적 매력과 개성을 표출하는 멋 내기의 한 방법이 되고 있다.

여러 가지 수염의 종류 가운데 서구문화에서 패셔너블하게 인식되어온 'Kaiser' 수염은 양쪽 끝이 위로 굽어 올라간 콧수 염으로, 19세기 말 독일 황제 빌헬름(Wilhelm) 2세의 수염 모 양에서 유래하였다(Fig. 29). 국어사전에도 정식으로 올라있는 이 단어는 독일 황제의 칭호로, 로마의 장군 카이사르에서 그 명칭이 유래되었다(“몸 이름”, 2009).

무성영화 후기인 1923년부터 제2차 세계대전 후까지 영국 영화배우로 활약한 로널드 콜먼(Ronald Colman)의 이름을 딴 'Colman' 수염(Fig. 30)은 당시 남성들 사이에서 굉장한 인기를 얻었다. 이는 미남배우 클라크 게이블(Clark Gable)의 모습에서 도 발견되는데(Fig. 31) 보통 잘생긴 남성들이 선호하는 스타일 로, 다소 건방져 보이는 플레이보이형의 수염이다(황현규, 2004). 한편, 스페인의 초현실주의 화가인 살바도르 달리의 수염은 좁고 긴 끝이 위로 굽어 올라간 형태로 다른 곳은 모두 면도 된 것이 특징인데, 후에 그의 이름을 따 'Dali' 수염으로 명명 되었다("Moustache", 2008). 그는 프로이드(Sigmund Freud)의 정신 분석 학설을 기반으로 꿈이나 환상의 세계와 같은 비합리 적인 환각을 객관적-사실적으로 표현한 천재화가이다(Fig. 4). Fig. 32 에서는 수염을 두 갈래씩 땅아 고양이 수염처럼 독특한 형태로 표현하였으며 해학 넘치는 눈과 얼굴표정으로 웃음을 자아낸다. 그의 수염은 초현실주의적이고 기상천외한 작품들과 연관되어 주목을 받았으며 주체할 수 없는 개성의 표현이라는 예술가로서의 면모를 보여준다.

1980년대 영화배우 돈 존슨(Don Johnson)과 조지 클루니 (George Clooney)는 아침 면도 후 낮 동안 자란 수염을 의미 하는 'Five o'clock shadow'(Fig. 33)라는 전체적으로 가볍게
기른 수염으로 스타일링하였다. 특히 할리우드 최고의 섹시스 타로 인식되는 클루니는 배우, 영화감독 일뿐 아니라 자유주의 정치 행동가로서 2009년 1월 31일 UN(United Nations)에 의 해 '평화의 메신저'(Messenger of Peace)라는 명칭을 얻게 되 었다(“UN gives", 2008). 이와 어울리게 그의 수염은 열심히 일하고 몸으로 실천하는 행동가로서의 이미지를 완성시켜준다. 수염의 개성적 표현은 주로 예술가와 연예인 스타들을 중심 으로 시작되어 셀리브리티(celebrity)로서의 매력적인 스타일링, 일반인과의 차별화 또는 극중 캐릭터의 성격을 묘사하기 위한 방법으로 사용되고 있는 것으로 보인다. 이는 미디어를 통해 대 중에게 확산되었고 오늘날 패션과 외모에 관심이 많은 남성, 즉 메트로섹슈얼(Metrosexual) 사이에서는 수염을 통해 자유, 개성, 성적 매력을 표현하는 상징물로 부각되고 있다. 수염은 이제 전 근대적 상징 또는 불결함이라는 허물을 벗고 하나의 패션 아이 템이 되고 있다고 할 수 있다.

\section{4. 종교적 권위}

오늘날 수염에 대한 법적 제재는 사라졌지만 세계의 정치적, 문화적 환경의 급변속에서도 관습과 종교의 영향은 여전히 지 속되고 있으며 특히 힌두교, 유대교, 이슬람교에서 종교적 권위 를 상징하는 형태들이 남아 있다.

힌두인들은 정치적 신분제도인 카스트(Caste)와 선종의 시조 달마(Dharma)를 숭배하는 의미로 수염을 기른다. 탁발승을 제 외한 많은 힌두 성직자들은 순결의 상징으로 면도를 하지 않으 며, 수염의 숱이 적은 경우 사악하거나 나약한 것으로 간주된 다. 많은 고행자와 요가 수행자들 또한 수염을 기르는데 이는 방랑적 생활과 고행을 상징한다(Fig. 34). 또한 유대교에서 수 염과 머리카락은 생명을 의미하는 것으로, 정통 유대인들은 현 대에도 상의가 긴 검정색 정장에 신사모자, 풍성하고 긴 콧수 염과 턱수염, 구레나룻, 양쪽 귀에 브레이드 헤어(Braid hair)를 길게 늘어뜨리고 있다. Fig. 35 는 정통 유대인의 모습으로, 옛 것을 지키고자 하는 전근대적이며 고집스러운 인상을 준다. 탈 무드(Talmud) 전통에서는 칼날이 하나인 면도날이 피부에 직접 닿아 수염을 손상시키기 때문에 면도날로 면도하는 것을 허락 하지 않는다. 그러나 가위는 칼날이 두개이므로 피부에 닿지 않 고 칼날 두개가 부딪혀 수염이 잘리므로 가위 사용은 허용된다. 이러한 연유로 유대교 법률 결정자들은, 정통 유대인들은 남아

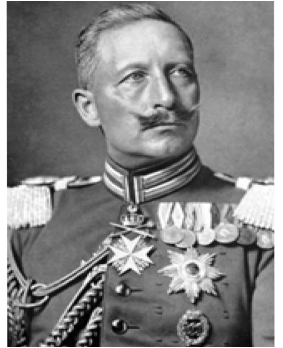

Fig. 29. Wilhelm II

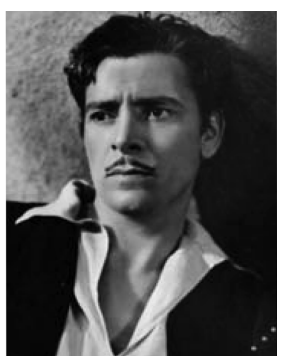

Fig. 30. Colman

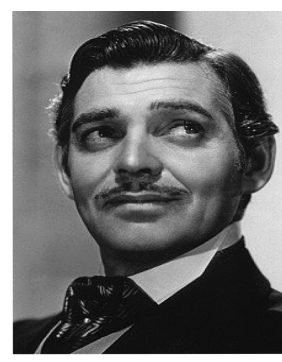

Fig. 31. Gable

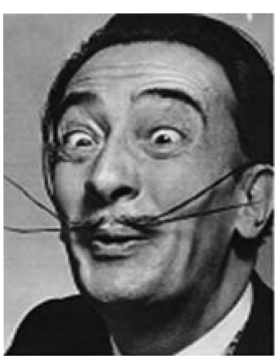

Fig. 32. Dali

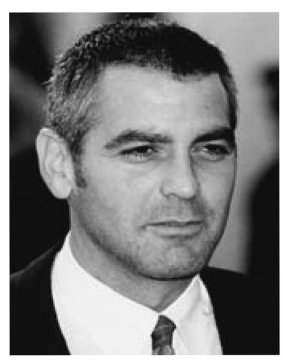

Fig. 33. Clooney 


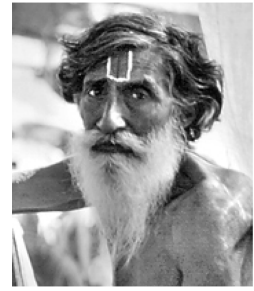

Fig. 34. 힌두교 수행자

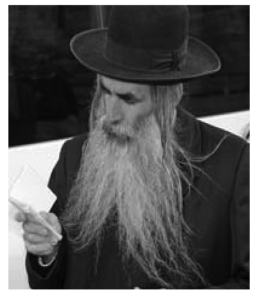

Fig. 35. 유대인

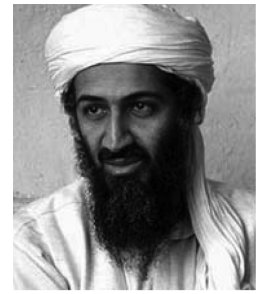

Fig. 36. 무슬림
있는 수염까지 깨끗하게 면도하기 위해 전기면도기를 사용해야 한다는 율법을 정하였다. 따라서 전기면도기가 출현할 때까지 정통 유대인들은 사회적, 문화적 이유로 수염을 길러왔는데 수 염은 조상의 전통을 지키는 의미를 가졌기 때문이다. 유대 신 비교의 주해서 조하(Zohar)는 수염에 신성성을 부여하고, 수염 의 털들은 위로부터 잠재적 신성 에너지가 인간의 영혼에 내려 오는 채널로 상징화되었다. 따라서 팔레스타인의 경건파 유대 교도인 하시드(Hasid)인들은 신비철학이 그들의 종교적 수행에 중요한 역할을 한다고 보고 전통적으로 수염을 깎거나 다듬지 도 않았다. 한편, 이슬람교의 창시자 마호메트(Muhammad)는 무슬림(Muslim)들에게 아랍 이교도와 조로아스터(Zoroaster)교 인들과의 차별화를 위해 턱수염 면도를 금지하고 콧수염을 다 듬을 것을 명하였다. 강제력이 있는 것은 아니지만 이슬람 전 통에서 알라신(Allah)이 히브리족의 시조 아브라함(Abraham)에 게 턱수염을 기르고 콧수염과 손톱은 다듬고, 성기 주변과 겨 드랑이 털은 제모를 명함에 따라 일반적으로 이를 따르고 있다 ("Beard", 2009). Fig. 36은 무슬림인 세계적 테러리스트 오사 마 빈 라덴(Osama bin Laden)의 모습으로, 턱수염과 구레나룻 은 풍성하나 콧수염은 짧게 잘 다듬어져 있다. 흰색 터번을 포 함한 무슬림 복장과 검은색 수염이 시각적인 대조를 이루어 강 한 인상을 준다.

위와 같이 종교적 권위를 상징하는 수염의 형태는 수염이 순 결, 생명, 신성성을 의미하는 만큼 길고 풍성하고 잘 다듬어지 지 않은 자연스러운 형태를 띠고 있음을 알 수 있다.

\section{4. 요약 및 결론}

역사적 담론에서, 수염패션은 많은 변화를 겪어왔다. 남성들 은 지역적 관습이나 종교, 법률, 그 시대의 유행 스타일에 따 라 수염을 기르고 손질하고 정돈하거나 또한 같은 이유로 제거 하였다.

수염이 제도권내에 있을 때 수염은 남성다움, 건강, 권력, 명 예의 상징으로 간주되었고 면도가 규정되어있을 때 수염은 비 정상적인 것이었다(Sherrow, 2006). 또한 수염은 지적-성적 매 력 또는 사회적 지위와 같은 특질들을 지니는 반면, 트램프 (Tramp), 호보(Hobo)와 같은 광대나 부랑자처럼 불결함, 거침, 괴상한 기질을 나타내기도 한다. 따라서 수염은 미 또는 추의 절대적 가치를 지니기 보다는 시대, 문화, 개인적 특성에 따라
상대적 가치를 지닌다고 할 수 있다.

따라서 논자는 수염을 사회문화적 의미를 표출하는 요소로 규정하고, 현대 남성 수염 스타일의 상징적 가치에 대한 고찰 을 목적으로 본 연구를 진행하였으며, 특히 전근대성의 종말과 현대화로 인해 수염의 사회문화적 의미의 가변성이 두드러진 20세기 서구를 중심으로 수염 문화와 수염 스타일의 상징적 가 치를 분석하였다. 연구의 요약 및 결과는 다음과 같다.

첫째, 수염은 사춘기 이후 남성 호르몬의 작용에 의해 생기 는 제 2 차 성징으로, 성숙한 남자의 입가 - 턱 - 볼에 나는 털을 의미하는 전형적인 남성적 특성이다. 수염은 나는 부위에 따라 크게 콧수염(Moustache), 턱수염(Beard), 전체 수염(Full Beard)으 로 나뉘며 각각의 형태에 따라 콧수염에는 'Natural', 'English', 'Hungarian', 'Handlebar', 'Dali', 'Fu Manchu', 'Freestyle', 턱수 염에는 'Natural', 'Musketeer', 'Goatee', 'Sideburns', 'Freestyle', 전체 수염에는 'Natural', 'Garibaldi', 'Verdi', 'Van Dyck', 'Freestyle'이 있다.

둘째, 수염의 역사를 살펴보면 고대는 가짜 수염과 면도가 시작된 시기로, 대부분의 고대국가에서는 수염이 계급, 지식, 존 엄의 상징으로서 컬을 하거나 금사, 금색 분말을 사용하여 장 식을 하는 등 소중하게 다루어졌다. 반면 마케도니아와 로마에 서는 면도를 도입하여 다른 국가와의 차별화를 시도하였다. 중 세는 수염을 규제한 시기로, 세속적이라는 이유로 교회가 머리 카락과 수염을 금지하는 법령을 제정하였다. 근세는 수염의 혼 란기로, 르네상스 시대에는 인본주의를 반영하듯 수염의 형태와 길이에 대한 규제가 없어 다양한 수염들이 유행하였던 반면, 17 세기 이후에는 수염이 시대에 뒤떨어진 것으로 여겨져 수염이 사라졌으며 오히려 가발의 부피가 커지고 화려해졌다. 근대는 수염이 대중화된 시기로, 가발이 사라지고 수염이 일반화 되었 다. 19세기 후반 대부분의 사람들은 턱수염, 콧수염, 구레나룻 의 다양한 결합으로 수염을 길렀다. 현대는 1895 년 질레트사가 면도기를 발명한 이래, 면도가 주류문화로 정착된 시기이자 개 인적 취향에 따라 수염이 패션화된 시기이다.

셋째, 20세기 남성 수염 스타일에 영향을 미친 사회문화적 요인으로 세계정세의 변화, 포스트모더니즘에 의한 반문화, 대 중문화의 형성 및 전통문화의 혼재를 상정하고, 이에 따른 수 염 스타일의 상징적 가치를 정치적 독재, 사회적 반항, 개성적 표현, 종교적 권위로 나누어 고찰하였다. 정치적 독재를 상징하 는 수염은 히틀러의 Chaplin 수염, 후세인의 Moustache, 카스 트로의 Musketeer 수염에서 발견되는데 깔끔하게 정리된 이들 의 수염은 강한 눈빛, 굳은 결의를 보여주는 꼭 다문 입술과 어우러져 더욱 카리스마 넘치는 강인한 인상을 보여준다. 사회 적 반항을 상징하는 수염은 1950-70년대 청년 하위문화인 힙 스터의 Goatee 수염, 바이커의 Horseshoe 수염, 비트 제너레이 션의 Goatee 수염, 히피의 Natural 수염에서 발견된다. 이는 20 세기 면도문화 속에서 시대에 순응하지 않는 비동조성과 불 만을 표시하는 하나의 방법으로 수염 스타일을 이용한 것으로 분석된다. 개성적 표현을 상징하는 수염은 영화배우 로널드 콜 
먼과 클라크 게이블의 Colman 수염, 돈 존슨과 조지 클루니의 Five o'clock shadow 수염, 초현실주의 화가 살바도르 달리의 Dali 수염 등에서 발견되며 주로 연예인과 예술가들에서 시작 하여 일반인에게 확산되는 등 수염을 통해 자유와 개인적 취향 을 표출하고 있다. 또한 오늘날 수염에 대한 법적 제재는 사라 졌지만 힌두교, 유대교, 이슬람교에서 종교적 권위를 상징하는 형태들이 남아 있는데, 그들의 수염이 순결, 생명, 신성성을 의 미하는 만큼 길고 풍성하고 잘 다듬어지지 않은 Natural 수염 형태를 띠고 있다.

상기에서 살펴본 바와 같이 20 세기 서구 남성 수염은 본래 적 가치인 남성성, 계급, 권위 이외에 포스트모더니즘의 가치전 복 아래 주류문화에 대항하는 반문화와 대중문화의 상징, 전통 문화의 혼재라는 사회문화적 요인을 통해 정치적 독재, 사회적 반항, 개성적 표현, 종교적 권위라는 상징적 가치를 띠고 있음 을 알 수 있었다. 20 세기의 특이할만한 점은 과거와 달리 현대 남성들은 수염에 패션성을 부여하고 타인과의 차별화, 섹시한 이미지의 표출 등 개성과 매력을 중시하는 경향이 있다는 점이 다. 이는 연예인에게 한정된 것이 아닌 일반적 현상으로서 21 세기 메트로 섹슈얼(metro-sexual)에까지 확대되고 있다.

연구의 한계점으로는 수염에 대한 문헌 자료의 제한과, 20 세 기 남성 수염스타일의 상징적 가치가 논자의 주관적인 분류에 의해 분석이 이루어진 점을 들 수 있다. 본 연구가 앞으로 더 욱 심도 있는 연구를 위한 초석이 되길 바란다.

\section{참고문헌}

강명주. (2003). 무대분장의 표현기법에 관한 연구: 연극 '햄릿머산) 등을 중심으로. 한성대학교 예술대학원 석사학위논문.

김경희, 문윤경, 김서영. (2007). 17세기 남성헤어스타일 변화에 따른 남성이미지 연구: 머리와 수염스타일을 중심으로. 한국의상디자 인학회지, 9(3), 205-220.

김용선. (2008). 사극드라마의 수염설정에 따른 분장 이미지에 관한 연구. 코리아뷰티디자인학회지, 4(1), 49-55.

박대현. (2007). 수염분장에 따른 얼굴 캐릭터 이미지 변화 연구. 중
앙대학교 예술대학원 석사학위논문.

양미경. (2003). 하위문화 복식의 스타일 연구 -1930년대부터 1990년 대까지. 성신여자대학교 대학원 박사학위논문.

윤수경. (2003). 저항적 하위문화로서의 히피와 그 전후 스타일에 관 한 연구. 세종대학교 대학원 박사학위논문.

황현규. (2004). 한번 보고 사람을 아는 법. 서울: 시간과 공간사, p.65.

Corson, R. (2005). Fashions in Hair: the First Five Thousand Years. London: Peter Owen, p.27.

Polhemus, T. (1994). Street Style. New York: Thames \& Hudson, pp.26-29.

Sherrow, V. (2006). Encyclopedia of Hair. Westport: Greenwood Press, pp.56-61, 283-284, 407-408.

Beard. (2009, April 7). Wikipedia. Retrieved April 9, 2009. from www.wikipedia.org

Beat Generation. (2009, August 4). Wikipedia. Retrieved August 6, 2009. from www.wikipedia.org

Beatnik. (2009, July 29). Wikipedia. Retrieved August 6, 2009. from www.wikipedia.org

Fu Manchu moustache. (2009, July 27). Wikipedia. Retrieved August 10, 2009. from www.wikipedia.org

Moustache. (2008, May 6). Wikipedia. Retrieved April 10, 2009. from www.wikipedia.org

Sideburns. (2008, September 9). Wikipedia. Retrieved August 10, 2009. from www.wikipedia.org

UN gives actor Clooney peace role. (2008, February 1). BBC News. Retrieved August 6, 2009. from http://news.bbc.co.uk/1/hi/enter tainment/7220701.stm

몸 이름 바로알기 (5). (2009, 1. 30). 한경닷컴. 자료검색일 2009, 8. 5. 자료출처 www.hankyung.com

사담 후세인. $(2009,7$. 26). 위키백과. 자료검색일 2009, 8. 11. 자 료출처 http://ko.wikipedia.org

파란의 인생역정 피델 카스트로... 그는 누구인가. $(2008,2.20)$. 한국 일보. 자료검색일 2009, 8. 11. 자료출처 http://news.hankooki.com

히틀러. (2004, 1. 1). noblemann. communications. 자료검색일 2009, 8. 11. 자료출처 www.nobelmann.com/old/peoples/hitler/hitler.htm

(2009년 9월 23일 접수/ 2009년 11 월 2일 1차 수정/ 2009년 12월 4일 2차 수정/ 2009년 12월 4일 게재확정) 